\title{
Studi Pendahuluan Hubungan Panjang-Berat Ikan Tenggiri (Scomberomorus commerson) dari Perairan Semarang
}

\author{
Adi Santoso*, Endang Sri Susilo \\ Departemen IImu Kelautan, Fakultas Perikanan dan IImu kelautan, Universitas Diponegoro \\ JI. Prof. Soedarto, SH. Kampus UNDIP Tembalang, Semarang 50275 \\ Email: adisantoso1959@gmail.com
}

\begin{abstract}
Length-weight relationship study of narrow-barred spanish mackerel (Scomberomorus commerson) from Semarang waters was commenced in October-November 2014. The result showed that the fish growth at both the months of October and November 2014 was a negative allometric growth. There was uncertainty to answer the low value for b component during November although at this month was a peak of the fish catching at Java Sea. Due to small fish landed, it indicated that narrow-barred Spanish mackerel of Semarang waters were not proper to be caught.
\end{abstract}

Keywords : narrow-barred Spanish mackerel, length-weight relationship, allometric growth

\begin{abstract}
Abstrak
Studi hubungan panjang-berat ikan tenggiri (Scomberomorus commerson) dari perairan Semarang sudah dilakukan selama bulan Oktober dan November 2014. Hasil penelitian menunjukkan bahwa pertumbuhan ikan tenggiri selama bulan Oktober maupun November 2014 adalah bersifat allometrik negative. Tidak diketahui dengan pasti penyebab kecilnya nilai b terutama pada bulan November, meskipun pada periode tersebut merupakan salah satu puncak musim penangkapan ikan tenggiri di Laut Jawa. Kecilnya ukuran ikan yang didaratkan, menunjukkan bahwa ukuran ikan tenggiri di perairan Semarang belum layak tangkap.
\end{abstract}

Kata kunci: ikan tenggiri, hubungan panjang-berat, pertumbuhan allometrik

\section{PENDAHULUAN}

Ikan tenggiri (Scomberomorus commerson/merupakan jenis ikan yang tergolong ekonomis penting dan menjadi salah satu ikan yang digemari di dunia. Ikan epipelagis dan bersifat migratory ini penyebarannya mencakup seluruh wilayah Pasifik Barat dari Afrika Utara dan Laut Merah sampai ke perairan Indonesia, Australia,dan Fiji ke utara sampai ke perairan China dan Jepang (McPherson, 1993). Spesies ikan ini menyukai habitat dangkal di continental shelf terutama dikaitkan dengan keberadaan terumbu karang sampai kedalaman 10-70 m (McPherson, 1985; Myers, 1991). Ikan tenggiri juvenile dan masih muda hidup dalam gerombolan kecil, sedangkan yang sudah dewasa sebagai individual (Collette, 2001).

Menurut Widodo \& Burhanuddin (2003), salah satu sumberdaya perikanan yang telah lama dieksploitasi di perairan Laut Jawa adalah ikan dari suku scombridae termasuk didalamnya jenis ikan tenggiri (Scomberomorus commerson), tongkol komo (Euthynnus affinis), maupun kembung (Rastrelliger brachisoma). Khusus ikan tenggiri, yang dikenal dalam perdagangan internasional sebagai narrow-barred spanish mackerel, memiliki nilai ekonomis tinggi karena permintaan domestik dan dunia yang terus meningkat dan harga yang semakin 
tinggi (Kasim dan Triharyuni, 2014). Pada tahun 2011 produksi perikanan Laut Jawa hanya mencapai 861.711 ton atau sebesar $16,1 \%$ dari total produksi perikanan nasional dimana ikan tenggiri yang didaratkan berkonntribusi sebesar $2,6 \%$ dari total pendaratan ikan di utara Jawa. Produksi ini ditunjang 83.142 unit kapal penangkap ikan yang beroperasi di Laut Jawa atau sekitar $14 \%$ dari total jumlah kapal tangkap ikan yang beroperasi di seluruh perairan Indonesia (Statistik perikanan Tangkap, 2013).

Hubungan antara panjang-berat sering digunakan untuk mengestimasi biomasa stok ikan tertentu, menghitung indek kondisi dan perubahan-perubahan ontogegeny (Safran, 1992) dan studi pertumbuhan (Moutopoulos and Stergion, 2002). Bahkan, Froese (2006) menyatakan bahwa dengan studi hubungan panjangberat suatu spesies akan lebih menajamkan dalam mempelajari ekologinya. Untuk tujuan pengelolaan sumberdaya perikanan, pengetahuan berbagai parameter populasi mutlak diperlukan. Dalam konteks ini, tujuan dari penelitian ini adalah untuk mengestimasi hubungn panjang-berat dari ikan tenggiri yang ada di perairan Semarang.

\section{MATERI DAN METODE}

Sampel ikan tenggiri tanpa membedakan jenis kelaminnya dikoleksi selama bulan Oktober dan November 2014 dari pengepul di Tambaklorok, Semarang. Pengepul memperoleh ikan dari nelayan yang menangkap ikan di perairan Semarang dan didaratkan di Tempat Pelelangan Ikan (TPI) Tambaklorok Semarang.

Panjang ikan (mm) yang diukur adalah panjang total, yaitu panjang ikan yang diukur mulai dari ujung terdepan dari kepala sampai ujung terakhir bagian ekornya. Berat ikan (g) diukur sebagai berat basah.

Analisis data sampel dilakukan dengan mengamati hubungan panjangberat ikan sehingga kita dapat mengetahui pola pertumbuhan ikan, serta berat ikan dapat dianggap sebagai fungsi dari panjangnya (Effendie, 1997):

$$
\begin{aligned}
& W=a L^{b} \\
& \log W=\log a+b(\log L) \\
& \text { Dimana: } \\
& W=\text { berat ikan } \\
& L=\text { panjang ikan } \\
& a \text { dan } b=\text { konstanta }
\end{aligned}
$$

Aplikasi terbaik dalam hubungan panjang-berat, menurut Ricker (1975) terjadi bila panjang dan berat ikan secara individu diukur dalam waktu beberapa tahun secara berturutan (successive years). Nilai b ditentukan dari plotting logarima berat terhadap logaritma panjang dari sejumlah besar ikan dari berbagai ukuran, maka slope yang dihasilkan merupakan nilai b yang diestimasikan (koefisien regresi). Apabila b = 3 maka dinamakan dengan isometrik yang menunjukkan ikan tidak berubah bentuknya dan pertambahan panjang ikan seimbang dengan pertambahan beratnya. Apabila $b<3$ dinamakan alometrik negatif, bila pertumbuhan panjangnya lebih cepat dibandingkan pertumbuhan beratnya, jika $b>3$ dinamakan alometrik positif yang menunjukkan bahawa pertumbuhan beratnya lebih cepat dibandingkan dengan pertambahan panjangnya (Effendie,1997).

\section{HASIL DAN PEMBAHASAN}

Sampel ikan yang dikoleksi dari pengepul di Tambaklorok Semarang selama bulan Oktober 2014 sebanyak 28 ekor dan selama bulan November 2014 sebanyak 29 ekor (Tabel 1). Secara umum panjang total ikan tenggiri rata-rata pada bulan Oktober $(279,9 \mathrm{~mm})$ lebih besar dibandingkan bulan November 2014 (254 $\mathrm{mm})$, demikian juga dalam berat basah. Rata-rata berat basah pada bulan Oktober 2014 sebesar 157,2 g, dan pada bulan November 2014 sebesar 129,6 g. Tetapi, variasi penyebaran data lebih besar terjadi pada bulan November 2014. 
Analisa beda nilai tengah panjang total ikan dengan uju $T$ sampel berpasangan hasilnya berbeda nyata (Sig 0,002<0,05).

Hubungan panjang-berat dapat dilihat pada Gambar 1, yang digambarkan dalam matriks scatter plot, dan Gambar 2.

Dari total 28 ekor ikan tenggiri pada bulan Oktober didapatkan panjang ratarata $279,9 \pm 44,84 \mathrm{~mm}$ dan berat rata-rata $157,29 \pm 69,03$ g. Pertumbuhan S. commerson pada bulan tersebut adalah allometrik negative dengan nilai $b$ terhitung 2,73 $\left(R^{2}=0,950\right)$. Sedangkan, dari total 29 ekor ikan tenggiri pada bulan November didapatkan panjang rata-rata $254,0 \pm 78,34 \mathrm{~mm}$ dan berat rata-rata $129,55 \pm 110,97$ g. Pertumbuhan S. commerson pada bulan November seperti halnya pada bulan sebelumnya, yaitu allometrik negative dengan nilai $b$ terhitung yang lebih kecil lagi sebesar 2,34 $\left(R^{2}=0,975\right)$. Rendahnya nilai $b$ mengindikasikan bahwa pertambahan panjang lebih cepat dibandingkan dengan pertambahan berat. Keadaan seperti ini ditunjukkan dengan keadaan ikan yang terlihat lebih langsing, terutama untuk ikan-ikan sampel bulan November.

Selama penelitian, untuk bulan Oktober sebetulnya bukan musim penangkapan ikan tenggiri di Laut Jawa, sebab dari bulan Juli sampai Oktober merupakan bulan yang bukan musim ikan tenggiri (Kasim dan Triharyuni, 2014). Sebaliknya, masih menurut Kasim dan Triharyuni (2014) untuk bulan November bersama-sama bulan April merupakan bulan puncak musim penangkapan ikan tenggiri di Laut Jawa, termasuk juga perairan Semarang tentunya. Adanya variasi suhu dan salinitas secara tahunan antara perairan Laut Jawa dan perairan oseanik, akan mempengaruhi distribusi dan kelimpahan ikan tenggiri khususnya pada musim peralihan sehingga pada bulan April dan November ikan tenggiri cenderung melimpah sepanjang tahun. Sangat sulit untuk menjelaskan alasan bahwa nilai b nilainya kecil $(2,34)$ saat ikan melimpah. Justru ikan-ikan pelagis besar bermigrasi dengan tujuan mencari makan (Sumadhiharga, 2009), dan ikan tenggiri bermigrasi ditandai dengan melimpahnya makanan (Noegroho, 2013).

Tabel 1. Analisa data panjang dan berat basah ikan tenggiri (Scomberomorus commerson) di perairan Semarang selama bulan Oktober dan November 2014

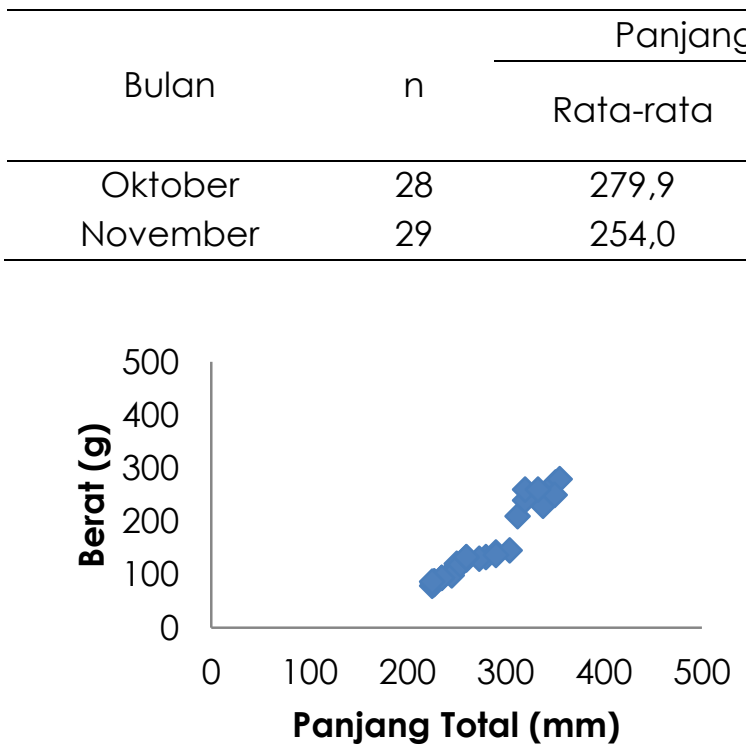

(a)

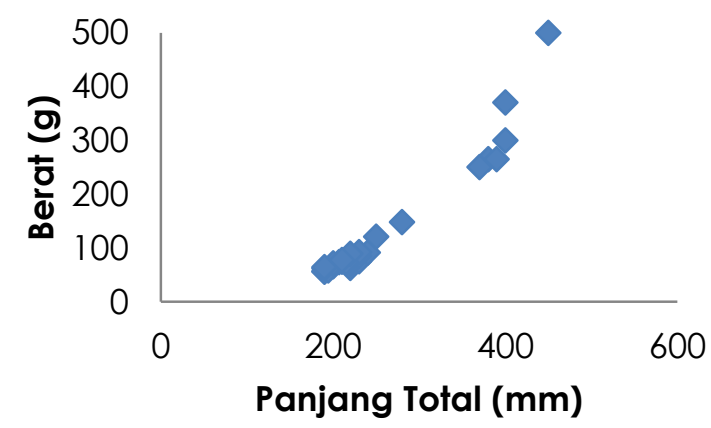

(b)

Gambar 1. Matriks scatter plot hubungan panjang-berat ikan tenggiri (Scomberomorus commerson) di perairan Semarang selama bulan Oktober (a) dan November (b) 2014 


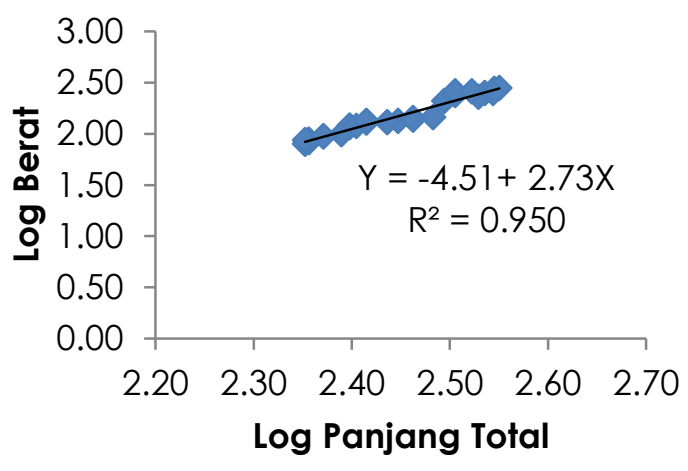

(a)

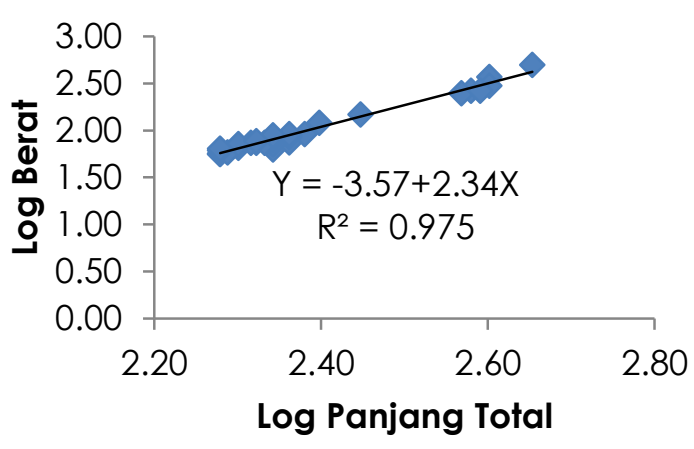

(b)

Gambar 2. Hubungan panjang-berat ikan tenggiri (Scomberomorus commerson) di perairan Semarang selama bulan Oktober (a) dan November (b) 2014

Dari ukuran panjang tubuh sampel ikan, baik untuk bulan Oktober maupun November, dapat dikategorikan ikan tenggiri yang ditangkap di perairan Semarang berukuran relative kecil dan belum layak tangkap. Ukuran panjang ikan hasil tangkapan dapat digunakan untuk menentukan layak atau tidaknya ikan tersebut untuk ditangkap dengan mengetahui batasan ukuran panjang ikan tersebut pertama kali matang gonad (length at first maturity). Penelitian Noegroho (2013) menunjukkan bahwa tenggiri matang gonad untuk pertama kali berukuran panjang sekitar $80 \mathrm{~cm}$ di perairan Laut Sulawesi, sekitar $75 \mathrm{~cm}$ di Laut Jawa, dan sekitar $65 \mathrm{~cm}$ di Bangka Belitung.

\section{KESIMPULAN}

Dari hasil analisis hubungan panjangberat S. commerson di perairan Semarang dapat diketahui bahwa pertumbuhan ikan selama bulan Oktober dan November 2014 adalah bersifat allometrik negative. Pengambilan sampel seharusnya selama satu tahun penuh (yearly), sehingga penelitian ini baru merupakan penelitian pendahuluan karena hanya dalam periode waktu 2 bulan yang perlu ditindak lanjuti.

\section{UCAPAN TERIMAKASIH}

Terimakasih kepada mahasiswa kami terkasih, Ikhwan Mussadad Cholid, yang membantu di lapangan. Sadad sendiri saat itu sedang disibukkan dengan penyusunan draft skripsinya.

\section{DAFTAR PUSTAKA}

Collette, B.B., 2001. Tunas (also, Albacore, Bonitos, Mackerels, Seerfishes and Wahoo). In: FAO Species Identification Guide for Fishery Purposes: The Living Marine Resources of the Western Central Pacific, Carpenter, K.E. and V. Niem (Eds.). Food and Agricultural Organization, Rome, pp: 3721-3756.

Collette, B.B. and Naven, C.E., 1983. FAO Species Catalogue. Vol 2. Scombrids of the world and annotated and illustrated catalogue of tunas, Mackerels, Bonitos and related species known to date. FAO Fisheries Synopsis 125(2), 137.

Effendie, M. I. 1979. Metoda Biologi Perikanan, Edisi 1. Yayasan Dewi Sri, Bogor, $112 \mathrm{hlm}$.

Froese, R. 2006. Cube law, condition factor and weight-length relationships: history, meta-analysis and recommendations. Journal of Applied Ichthyology 22 (4): 241-253

Kasim, K. dan S. Triharyuni. 2014. Status pemanfaatan dan musim penangkapan ikan tenggiri (Scomberomorus spp.) di Laut Jawa. J. Lit. Perikan. Ind. Vol.20 No. 4: 235-242.

Martin-Smith K.M. (1996). Length/weight relationships of fishes in a diverse tropical freshwater community, 
Sabah, Malaysia. Journal of Fish Biology, 49: 731-734.

McPherson, G.R., 1985. Northern line fishery for mackerels still important. Aust. Fish., 8: 12-14.

McPherson, G.R., 1993. Reproductive biology of the Narrow- Barred Spanish Mackerel(Scomberomorus

commerson) in Queensland waters. Asian fisheries. Sci.. 6:169- 182.

Moutopoulos D.K., Stergiou K.I. 2002. Length-weight and length-length relationships of fish species from Aegean Sea (Greece). Applied Ichthyology, 18: 200-203.

Myers, R.F., 1991. Micronesian Reef Fishes: A Practical Guide to the Identification of the Coral

Noegroho, T. 2013. Penelitian aspek biologi dan penangkapan ikan tenggiri (S. commerson, Lacepede 1800) di perairan teluk Kuandang, laut Sulawesi. Tesis, Fakultas MIPA Universitas Indonesia, Depok: $82 \mathrm{hlm}$.

Reef Fishes of the Tropical Central and Western Pacific. 2nd Edn., Coral Graphics, Guam,USA., , Pages: 299.

Ricker, W.E. 1975. Computation and Interpretation of Biological Statistics of Fish Populations. Bulletin of the Fisheries Research Board of Canada 191. Department of Fisheries and Oceans Canada. Ottawa.

Safran P. (1992). Theoretical analysis of the weight-length relationship in fish juveniles. Marine Biology. 112: 545-551.

Statistik Perikanan Tangkap Indonesia. 2011. Direktorat Jenderal Perikanan Tangkap. Kementerian Kelautan dan Perikanan. Vol 12. No.1. 